\title{
PENGARUH PERUBAHAN TINGKAT PENGETAHUAN KESEHATAN GIGI DAN MULUT PADA PELAJAR USIA 7-8 TAHUN DI 2 SEKOLAH DASAR KECAMATAN MANDIANGIN KOTO SELAYAN KOTA BUKITTINGGI MELALUI PERMAINAN EDUKASI KEDOKTERAN GIGI
}

\author{
(EFFECTS OF CHANGES IN THE LEVEL OF KNOWLEDGE OF ORAL HEALTH \\ IN 7-8 YEARS OLD STUDENTS IN TWO ELEMENTARY SCHOOLS \\ MANDIANGIN KOTO SELAYAN DISTRICT OF BUKITTINGGI CITY \\ DENTISTRY EDUCATION THROUGH GAMES)
}

\author{
Dedi Sumantri $^{1}$, Yuniar Lestari ${ }^{2}$, Mustika Arini $^{3}$
}

\begin{abstract}
Abstrak
Prevalensi karies pada anak usia sekolah dasar di Sumatera Barat masih tinggi. Pendidikan kesehatan gigi dan mulut menjadi penting untuk meningkatkan status kesehatan gigi dan mulut pada anak oleh karena itu diperlukan pengembangan strategi baru pada pendidikan kesehatan gigi dan mulut. Salah satu caranya adalah dengan menggunakan permainan, karena anak biasanya cenderung menyukai perrmainan. Penelitian ini bertujuan untuk mengetahui pengaruh permainan edukasi kedokteran gigi dalam hal ini menggunakan media ular tangga dalam perubahan tingkat pengetahuan pelajar usia 7-8 tahun mengenai kesehatan gigi dan mulut. Disain Penelitian ini menggunakan metode eksperimental analitik dengan desain penelitian non equivalent pre and post test control group design. 41 orang pelajar pada 2 SD (SD 17 Manggis Ganting dan SD 03 Pulai Anak Air) usia 7-8 tahun dimasukkan ke dalam kelompok eksperimen dimana kelompok ini diberikan permainan edukasi kedokteran gigi dengan media permainan ular tangga dan 41 orang pelajar SD 17 Manggis Ganting dan SD 03 Pulai Anak Air usia 7-8 tahun lainnya dimasukkan ke dalam kelompok kontrol dimana kelompok ini tidak diberikan perlakuan apapun. Analisis data menggunakan Paired Samples T-Test dan Independent Samples T-Test dengan 0,05 sebagai derajat kepercayaannya. Hasil analisis didapatkan persentase rata-rata selisih tingkat pengetahuan pada kelompok eksperimen adalah 13,32\% $\pm 12,475$ dan pada kelompok kontrol adalah sebesar 4,44\% $\pm 11,713$ dengan analisis pretest dan postest menunjukkan kedua kelompok memiliki perbedaan yang bermaknadengan nilai $p=0,00(p<0,05)$. Permainan edukasi kedokteran gigi menggunakan media ular tangga memberikan pengaruh lebih baik dalam meningkatkan pengetahuan kesehatan gigi dan mulut dibandingkan dengan kelompok kontrol. Jadi untuk meningkatkan pengetahuan mengenai kesehatan gigi dan mulut, permainan edukasi kedokteran gigi ini dapat menjadi salah satu metode pendidikan kesehatan gigi dan mulut untuk pelajar usia 7-8 tahun.

Kata kunci : Pendidikan kesehatan gigi, permainan, pengetahuan, pelajar
\end{abstract}

\begin{abstract}
The prevalence of caries among school children in West Sumatera is still high. Dental health education is important in order to increase dental health status in children because of that the development of a new strategy in dental health education is needed. One of the way is by using game, because children usually like that media. This study was aimed to find out the effectiveness of dental education game by using snake and ladder as the media in changing 7-8years old student's knowledge about teeth and mouth. The method of this study was analytic experimental with non equivalent pre and post test control group design. Fourty one student's with 7-8 years old of two Elementary Schools ( 17 Manggis Ganting and 03 Pulai Anak Air elementary school) were used as the study sample of experiment group, this group was given dental
\end{abstract}

\footnotetext{
${ }^{1}$ Staf Pengajar Fakultas Kedokteran Gigi Universitas Andalas

${ }^{2}$ Staf Pengajar Fakultas Kedokteran Universitas Andalas

${ }^{3}$ Mahasiswa Fakultas Kedokteran Gigi Universitas Andalas
} 
education games method with snake and ladder games as the media and fourty one student's with 7-8 years old of 17 Manggis Ganting and 03 Pulai Anak Air elementary school were used as the control group where in this group was given nothing. Analysis of data was using Paired Samples T-Test and Independent Samples T-Test based on 0,05 as significant. The pretest and posttest analysis of knowledge showed that mean percentage of experiment group is $13,32 \% \pm 12,475$ and $4,44 \% \pm 11,713$ for the control group. Both of groups have significant difference where $p=0,00(p<0,05)$. Dental education games method with snake and ladder games as media was effective in increasing student's knowledge in comparing with the control group. So in order to increase dental health knowledge, dental education games could be use as one of dental education method for 7-8 years old students.

Key words : dental education, games, knowledge, student

\section{PENDAHULUAN}

Masalah utama dalam rongga mulut adalah karies gigi dan penyakit periodonta ${ }^{1}$. Dilihat dari prevalensinya, Supartinah mengatakan bahwa di negaranegara maju prevalensi karies gigi terus menurun sedangkan di negara-negara berkembang termasuk Indonesia ada kecenderungan kenaikan prevalensi penyakit tersebut ${ }^{1}$. Hal ini bisa dilihat dari prevalensi nasional masalah gigimulut di Indonesia yaitu 23,5\%, dengan prevalensi nasional karies aktif sebanyak 43,4\%. Padakelompok usia 5-9 tahun sebanyak 21,6 \% anak bermasalah dengan kesehatan gigi dan mulut namun hanya 30,9 \% dari yang bermasalah tersebut yang menerima perawatan ${ }^{2}$.

Salah satu penyebab timbulnya masalah kesehatan gigi dan mulut pada masyarakat adalah karena faktor perilaku atau sikap mengabaikan kebersihan gigi dan mulut, dimana perilaku dirumuskan sebagai totalitas penghayatan dan aktivitas seseorang yang merupakan hasil bersama atau resultante antara berbagai faktor, yang salah satu di antara faktor tersebut adalah pengetahuan ${ }^{3}$.

Pada penelitian yang dilakukan di SDN Geluran III kecamatan Taman, kabupaten Sidoarjo, Surabaya pada pelajar kelas 5 usia 10 sampai 13 tahun dengan jumlah sampel sebanyak 69 pelajar menunjukkan terdapat hubungan tingkat pengetahuan terhadap kejadian karies gigi, dimana penelitian ini menginformasikan mengenai kurangnya pengetahuan pelajar tentang cara pemeliharaan kesehatan gigi terutama dalam hal menggosok gigi ${ }^{4}$.

Untuk meningkatkan pengetahuan ini dapat dilakukan dengan pendidikan kesehatan atau penyuluhan. Dilihat dari segi usia rentannya anak yang terkena penyakit, maka penyuluhan terutama ditujukan pada golongan yang rawan terhadap gangguan kesehatan gigi dan mulut yaitu anak usia sekolah dasar. Oleh karena usia sekolah dasar yaitu usia 6-12 tahun merupakan usia transisi atau pergantian gigi desidui dengan gigi permanen (masa gigi bercampur). Di 
samping itu, anak usia sekolah dasar masih kurang dapat menjaga kebersihan gigi dan mulutnya. Menurut Wahyuningrum, upaya pemeliharaan kesehatan gigi dan mulut serta pembinaan kesehatan gigi pada anak usia sekolah dasar perlu mendapat perhatian khusus sebab pada usia ini anak sedang menjalani proses tumbuh kembang. Keadaan gigi sebelumnya akan berpengaruh terhadap perkembangan kesehatan gigi pada usia dewasa nanti ${ }^{1}$.

Ditinjau dari berbagai upaya pencegahan karies gigi pada anak usia sekolah dasar terdapat kegiatan UKGS (Usaha Kesehatan Gigi Sekolah) yang seharusnya dapat membuat angka karies pada anak usia sekolah dasar menjadi rendah, akan tetapi dilihat dari kenyataan yang ada dan berdasarkan laporanlaporan penelitian yang telah dilakukan, sebagian besar datanya menunjukkan adanya tingkat karies gigi yang cukup tinggi pada anak usia sekolah dasar ${ }^{1}$.

Pendidikan kesehatan sendiri sebenarnya dapat dilakukan dengan berbagai macam metode, seperti ceramah, seminar, curah pendapat, dan bermain $^{3}$. Kurang efektifnya kegiatan UKGS yang dijalankan bisa saja dikarenakan oleh metode penyampaian pendidikan kesehatan gigi dan mulut yang masih kurang optimal ${ }^{5}$. Untuk itu perlu digunakan pendekatan dengan cara lain yang lebih efektif dan bermanfaat bagi anak.

Salah satu metode yang efektif adalah dengan metode bermain yaitu suatu kegiatan dengan atau tanpa menggunakan sesuatu dimana diberikan kesenangan, informasi, bahkan imajinasi terhadap sesuatu tersebut ${ }^{6}$. Hasil penelitian Makuch membuktikan bahwa metode bermain dapat meningkatkan pengetahuan anak lebih baik dibandingkan dengan metode ceramah. Penelitian yang dilakukan oleh Fuller pada anak-anak SD di Inggris juga menunjukkan bahwa metode bermain telah menjadi pelopor kesehatan secara lisan dalam promosi kesehatan gigi dan mulut. Pada Penelitian Rusli kepada murid-murid SD St. Paulus kelas III dan V Jakarta Barat pun menunjukkan terdapat perbedaan bermakna pada peningkatan pengetahuan sebelum dan sesudah penyuluhan dengan metode bermain secara statistik ${ }^{7}$.

Data di Indonesia sendiri menunjukkan 23,4 \% masyarakat bermasalah dengan kesehatan gigi dan mulut dan penduduk Indonesia yang telah mendapatkan pendidikan kesehatan gigi dan mulut hanya $13,3 \%$, dimana Sumatera Barat menduduki tempat kedua terendah dengan persentase hanya $7,8 \%$ 
dari penduduknya yang telah menerima konseling perawatan dan kebersihan gigi ${ }^{2}$. Hal ini membawa dampak terhadap kurangnya pengetahuan masyarakat Sumatera Barat sendiri akan pentingnya pemeliharaan gigi dan mulut yang tergambar dari persentase Riskesnas tahun 2007 dimana 21,6\% masyarakat Sumatera Barat bermasalah dengan kesehatan gigi dan mulutnya.

Di Sumatera Barat, tinjauan mengenai kenyataan ini bisa dilihat dari Kota Bukittinggi, kota yang memiliki jumlah penduduk sebesar $111.312 \mathrm{jiwa} / \mathrm{km} 2$ ini memiliki program UKGS yang cukup aktif, dimana seluruh Puskesmas di setiap kecamatan memiliki program $\mathrm{UKGS}^{8}$. Namun pada pemeriksaan gigi dan mulut anak usia sekolah dasar di kota Bukittinggi, masih terdapat $10,8 \%$ anak bermasalah dengan kesehatan gigi dan mulutnya sehingga butuh perawatan kesehatan gigi dan mulut, dimana dalam hal ini kecamatan Mandiangin Koto Selayan menyumbangkan persentase terbesar dalam masalah kesehatan gigi dan mulut anak usia sekolah dasar di kota Bukittinggi yaitu sebesar $37 \%^{8}$.

Dalam pelayanan kesehatannya, kecamatan terluas di Bukittinggi ini memiliki 3 Puskesmas yaitu Puskesmas Mandiangin, Nilam Sari, dan Gulai Bancah. Dari data laporan pelayanan gigi dan mulut ketiga puskesmas tersebut, Puskesmas Nilam Sari menemukan prevalensi angka terbesar mengenai data anak usia sekolah dasar yang memerlukan perawatan gigi dan mulut yaitu sebesar 64,2\%. Berdasarkan persentase karies aktif dari penjaringan pelajar kelas 1 dan kelas 2 pada 7 SD binaan puskesmas tersebut pada periode 2010/2011 menunjukkan persentase terbesar terdapat pada SD Negeri 17 Manggis Ganting yaitu sebesar 89\%, dimana kegiatan UKGS berupa promosi kesehatan yang dilaksanakan pada SD tersebut adalah masih menggunakan metode ceramah ${ }^{9}$.

Berdasarkan alasan-alasan di atas peneliti tertarik untuk meneliti pengaruh permainan edukasi kedokteran gigi terhadap perubahan tingkat pengetahuan kesehatan gigi dan mulut pada pelajar usia 7-8 tahun di 2 Sekolah Dasar yaitu SD Negeri 17 Manggis Ganting dan SD Negeri 03 Pulai Anak Air Bukittinggi

\section{MATERI DAN METODE}

Kajian dalam penelitian ini adalah untuk mengetahui tingkat pengetahuan pelajar SD yang diukur sebelum dan sesudah diberikan permainan edukasi kedokteran gigi dibandingkan dengan yang tidak diberikan intervensi apapun.Desain penelitian ini adalah quasi 
experiment dengan rancangan non equivalent Pretest-Postest control group design.

Sampel pada penelitian ini adalah pelajar pada 2 buah SD yaitu SD 17 Manggis Ganting dan SD Negeri 03 Pulai Anak Air Bukittinggi Kecamatan Mandiangin Koto Selayan Kota Bukittinggi berusia 7-8 tahun yang memenuhi kriteria sebagai sampel subyek penelitian tidak diikut sertakan dalam penelitian bilatidak berada di sekolah saat pengumpulan data.

Pengambilan sampel dilakukan dengan metode simple random sampling.

Berdasarkan rumus uji hipotesis didapatkan jumlah sampel minimal 75 orang. Untuk menghindari drop out ditambah $10 \%$ yaitu 7 orang. Sehingga total sampel adalah 82 orang.

\section{Data Primer}

Data primer diperoleh dari responden dengan cara wawancara menggunakan kuisioner sebelum dan sesudah diberikan perlakuan oleh variabel independen (metode permainan).

\section{Data Sekunder}

Data sekunder diperoleh dari pencatatan dan pelaporan pelayanan kesehatan gigi dan mulut pelajar SD 17 Manggis Ganting dan SD Negeri 03 Pulai Anak Air Bukittinggi.
Pengumpulan data pribadi subjek penelitian untuk menyesuaikan dengan kriteria penelitian kemudian subjek penelitian mengisi informed consent.

Subjek penelitian menjawab pertanyaan dari kuesioner secara bersamaan dengan alokasi waktu yang telah ditentukan.

Kelompok subjek dibagi dua, satu kelompok eksperimen yang diberi perlakuan dengan permainan ular tangga dan satu kelompok lain yaitu kelompok kontrol tidak diberikan perlakuan apapun.

Setelah selesai bermain, kedua kelompok menjawab pertanyaan dari kuesioner yang sama dengan kuisioner pertama dengan alokasi waktu yang telah ditentukan. Kemudian dianalisa data dengan melihat hasil pretest dan postest nya.

\section{Pengukuran tingkat pengetahuan}

Pengukuran Tingkat pengetahuan kesehatan gigi dan mulut dilihat dari kemampuan responden dalam menjawab pertanyaan tentang kesehatan gigi dan mulut, yang meliputi tujuan menjaga kesehatan gigi dan mulut, cara menjaga kesehatan gigi dan mulut, penyebab sakitnya gigi, makanan yang dapat merusak gigi, makanan yang baik untuk gigi, akibat dari kurang menjaga kesehatan gigi dan mulut, tujuan 
menyikat gigi, cara menggosok gigi yang benar, waktu menyikat gigi yang tepat, cara memilih sikat gigi, cara menyimpan sikat gigi yang benar, waktu yang tepat untuk mengganti sikat gigi, anatomi gigi, jumlah gigi pada anak, dan mengenai waktu yang tepat untuk mengunjungi dokter gigi. Jawaban yang benar diberi nilai satu (1), dan yang salah nol (0).

Sedangkan untuk metode permainan edukasi kedokteran gigi yang dipakai dalam penelitian ini adalah permainan ular tangga. Dalam permainan ular tangga ini terdapat pesan-pesan kesehatan gigi dan mulut dalam setiap kotak pada papan permainan ular tangganya. Pesanpesan tersebut meliputi hal-hal yang sama yang juga ditanyakan pada kuisioner.

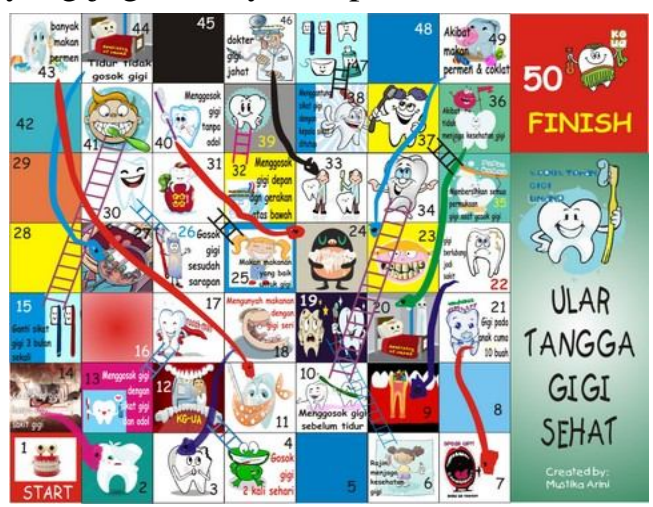

Gambar 1. Permainan Ular Tangga

\section{Analisis Data}

\section{Analisis Univariat}

Analisa univariat dilakukan untuk melihat distribusi data hasil kuisioner Pretest dan Postest dari masing-masing kelompok, baik kelompok eksperimen ataupun kontrol.

\section{Analisa Bivariat}

Analisis bivariat dilakukan secara deskriptif dengan uji statistik Paired t-test dan Independent t-test. Paired t-Test adalah pengukuran pada subyek yang sama terhadap suatu pengaruh atau perlakuan tertentu. Ukuran sebelum dan sesudah mengalami perlakuan tertentu diukur. Dasar pemikirannya yaitu apabila suatu perlakuan tidak memberi pengaruh, maka perbedaan rata-ratanya adalah nol. Independent sample t-test yaitu suatu pengujian signifikansi beda rata-rata antar dua kelompok. Pengujian ini biasanya digunakan untuk menguji pengaruh satu variabel independen terhadap satu atau lebih variabel dependen. Analisis dilakukan pada derajat kepercayaan $95 \%$ dan dikatakan bermakna apabila $\mathrm{p}<0,05$.

\section{HASIL PENELITIAN}

Hasil analisis didapatkan persentase rata-rata selisih tingkat pengetahuan pada kelompok eksperimen adalah 13,32\% $\pm 12,475$, sedangkan pada kelompok kontrol adalah sebesar 4,44\% $\pm 11,713$. Hal ini menunjukkan terdapat perbedaan rata-rata selisih tingkat pengetahuan kesehatan gigi dan mulut antara 
kelompok eksperimen yang diberi penyuluhan dengan media permainan edukasi kedokteran gigi dibandingkan dengan kelompok kontrol dimana nilai $\mathrm{p}<0,05$ yang berarti terdapat perbedaan yang bermakna dari tingkat pengetahuan kesehatan gigi dan mulut antara kelompok eksperimen yang diberikan penyuluhan menggunakan media permainan edukasi kedokteran gigi dibandingkan dengan dengan kelompok control

Tabel 1. Persentase Rata-rata Selisih Tingkat Pengetahuan Responden Antara Kelompok Eksperimen dengan Kelompok Kontrol (Independent t-test)

\begin{tabular}{|c|c|c|c|}
\hline \multirow{2}{*}{ Variabel } & Rath-rata & Standar Deviasí & \multirow{2}{*}{ pralue } \\
\hline & Eksperimen Kontiol & Eksperimen Kontrol & \\
\hline Sellisish & $13,32 \quad 4,44$ & $12,475 \quad 11,713$ & 0,001 \\
\hline Pengetahluan & & & \\
\hline
\end{tabular}

\section{PEMBAHASAN}

Hasil penelitian menunjukkan terdapat perbedaan rata-rata selisih antara kelompok eksperimen dan kelompok kontrol yang didukung oleh uji statistik dimana didapatkan nilai $\mathrm{p}<0,05$ yang berarti terdapat perbedaan yang bermakna dari tingkat pengetahuan kesehatan gigi dan mulut antara kelompok eksperimen yang diberikan penyuluhan menggunakan media permainan edukasi kedokteran gigi dibandingkan dengan kelompok kontrol.

Media ular tangga yang digunakan pada penelitian ini sebagai media edukasi kedokteran gigi menunjukkan bahwa media ular tangga dapat berfungsi dalam peningkatan tingkat pengetahuan responden. Hal ini sejalan dengan penelitian oleh Charina Amelia yang menunjukkan bahwa permainan ular tangga efektif dalam meningkatkan pengetahuan tentang bahaya rokok pada pelajar SMP Ma`arif Tegal. ${ }^{10}$.

$$
\text { Permainan edukasi dapat }
$$
meningkatkan kemampuan berfikir, berbahasa, serta bergaul dengan orang lain. Permainan edukasi merupakan permainan yang dirancang dan dibuat untuk merangsang daya pikir anak termasuk meningkatkan kemampuan berkonsentrasi dan memecahkan masalah $^{11}$. Penggunaan media ular tangga dapat digunakan sebagai media belajar sambil bermain. Proses pendidikan, pengembangan materi dapat dilakukan dengan berbagai cara, salah satunya adalah dengan optimalisasi media. Media visual diyakini dapat lebih meningkatkan motivasi anak dalam proses pendidikan terutama penggunaan media grafis yaitu media yang menuangkan pesan dalam 
bentuk tulisan, huruf-huruf, gambargambar, simbol-simbol, yang mengandung arti. Media grafis termasuk media visual diam sebagaimana halnya dengan media lain, media grafis mempunyai fungsi untuk menyalurkan pesan. Saluran yang dipakai menyangkut indera penglihatan yang dituangkan ke dalam simbol-simbol yang menarik dan jelas. Media ini termasuk media yang relatif murah dalam pengadaannya bila ditimbang dari segi biaya ${ }^{11}$. Penggunaan media grafis ini sering digunakan sebagai media permainan edukatif pada anak. Oleh karena itu dengan memainkan permainan ular tangga edukasi sebagai salah satu bentuk media grafis dari permainan edukasi kedokteran gigi diharapkan anak akan mudah memahami bagaimana menjaga kesehatan gigi dan mulut tersebut.

\section{KESIMPULAN}

1. Tingkat pengetahuan pelajar usia 78 tahun di di SD 17 Manggis Ganting dan SD Negeri 03 Pulai Anak Air Bukittinggi sebelum diberikan pendidikan kesehatan gigi dan mulut menggunakan metode permainan edukasi kedokteran gigi adalah tinggi.

2. Tingkat pengetahuan pelajar usia 78 tahun di SD 17 Manggis Ganting dan SD Negeri 03 Pulai Anak Air Bukittinggi sesudah diberikan pendidikan kesehatan gigi dan mulut menggunakan metode permainan edukasi kedokteran gigi adalah tinggi.

3. Terdapat perbedaan bermakna tingkat pengetahuan pelajar usia 7-8 tahun di SD 17 Manggis Ganting dan SD Negeri 03 Pulai Anak Air Bukittinggi setelah diberikan pendidikan kesehatan gigi dan mulut menggunakan metode permainan edukasi kedokteran gigi.

4. Tingkat pengetahuan pelajar usia 78 tahun di SD 17 Manggis Ganting dan SD Negeri 03 Pulai Anak Air Bukittinggi tanpa diberikan pendidikan kesehatan gigi dan mulut adalah rendah.

5. Terdapat perbedaan tingkat pengetahuan pelajar usia 7-8 tahun di SD 17 Manggis Ganting dan SD Negeri 03 Pulai Anak Air Bukittinggi tanpa diberikan pendidikan kesehatan gigi dan mulut.

6. Terdapat pengaruh permainan edukasi kedokteran gigi terhadap perubahan tingkat pengetahuan kesehatan gigi dan mulut pada pelajar usia 7-8 tahun di SD Negeri 17 Manggis Ganting dan SD Negeri 03 Pulai Anak Air Bukittinggi. 
7. Tidak terdapat perbedaan yang bermakna dari rata-rata selisih tingkat pengetahuan antara responden kelompok umur 7 tahun dan kelompok umur 8 tahun.

8. Tidak terdapat perbedaan yang bermakna dari rata-rata selisih tingkat pengetahuan antara responden SD 03 Pulai Anak Air dan SD 17 Manggis Ganting

\section{SARAN}

1. Promosi kesehatan gigi dan mulut yang diberikan oleh Puskesmas Nilam Sari kepada pelajar usia 7-8 tahun SD 03 Pulai Anak Air dan 17 Manggis Ganting selain mengajarkan cara menggosok gigi yang benar diharapkan juga dapat memberikan pengetahuan kesehatan gigi dan mulut lain terutama mengenai waktu yang tepat menggosok gigi yaitu sesudah sarapan dan sebelum tidur serta mengenai waktu kunjungan rutin ke dokter gigi setiap satu kali 6 bulan karena tingkat pengetahuan responden mengenai hal tersebut masih rendah.

2. Bagi Dinas Kesehatan Kota dan Puskesmas Nilam Sari dapat menggunakan metode permainan edukasi kedokteran gigi sebagai alternatif metode promosi kesehatan gigi dan mulut untuk anak usia 7-8 tahun selain menggunakan metode ceramah yang sering digunakan (Program UKGS)

3. Untuk penelitan lebih lanjut diharapkan dapat melakukan pengamatan dengan waktu yang lebih panjang karena keberhasilan pendidikan kesehatan baru dapat diukur dalam rentang waktu yang lebih panjang, serta dapat menguji perbedaan efektifitas permainan edukasi kedokteran gigi dengan media lain selain media permainan ular tangga dan menguji perbedaan metode efektifitas permainan edukasi kedokteran gigi dengan metodemetode promosi kesehatan gigi dan mulut lainnya.

\section{KEPUSTAKAAN}

1. Kawuryan, Uji. Hubungan Pengetahuan Tentang Kesehatan Gigi dan Mulut Dengan Kejadian Karies Gigi Anak SDN Kleco II Kelas V Dan VI Kecamatan Laweyan Surakarta. Diakses pada 30 November 2011; www.etd.eprints.ums.ac.id

2. Departemen Kesehatan. Riset Kesehatan Dasar 2007. Diakses pada 29 November 2011; www.riskesdas.litbang.depkes.go.id

3. Notoatmodjo, Soekidjo. 2003. Pendidikan dan Perilaku Kesehatan. Rineka Cipta, Jakarta.

4. Prasetyo, Kristina Puri Jati. Hubungan Tingkat Pengetahuan dan Frekuensi Konsumsi Kariogenik terhadap Kejadian Karies Gigi di SDN Geluran III Kecamatan Taman Kabupaten Sidoarjo. Diakses pada 2 Desember 2011; www.adln.lib.unair.ac.id 
5. Aliftiani, Ririn. 2010. Media Komik Sebagai Sarana Dental Health Education Pada Pelajar Usia 10-12 Tahun. Skripsi Universitas Airlangga, Surabaya

6. Gondhoyoewono, Tritana dan Meiske Rusli. Pengaruh Metode Bermain terhadap Penyuluhan Kesehatan Gigi dan Mulut. Diakese pada 26 Juli 2011; www.pdgionline.com

7. Mardhiyah, Haqqi. Efektifitas Metode Bermain Dalam Penyuluhan Kesehatan Gigi dan Mulut pada Pelajar Kelas VI SD Islam An-Nizam. Diakses pada 2 November 2011; www.library.usu.ac

8. Dinas Kesehatan Kota Bukittinggi. 2010. Profil Kesehatan kota Bukittinggi tahun 2010.Dinas Kesehatan Kota Bukittinggi, Bukittinggi
9. Puskesmas Nilam Sari. 2011. Laporan Pelayanan Gigi Dan Mulut Puskesmas Nilam Sari. Puskesmas Nilam Sari, Bukittinggi

10. Amelia,Charina.2010. Efektivitas Permainan Ular Tangga Untuk Meningkatkan Pengetahuan Tentang Bahaya Pelajar Kelas VII dan VIII SMP Ma`arif NU Tegal Tahun 2010. Diakses pada 20 Februari 2012; www.lin.unnes.ac.id/3801/

11. Dewi, Anita Lusia dkk.2011. Peningkatan Pengetahuan Gizi Anak Usia Sekolah melalui Pendidikan Jasmani dan Kesehatan (Penjaskes) Menggunakan Media Ular Tangga.Diakses pada 24 Februari 2012; www.repository.ipb.ac.id/bitstream/handle/1 23 